\title{
Social Support Impact on Academic Self- Concept of Students with Special Needs
}

Fitria Dwi Pratiwi ${ }^{1}$, Frieda Mangunsong ${ }^{2}$

${ }^{1}$ Department of Psychology, Universitas Indonesia, Depok

${ }^{2}$ Department of Psychology, Universitas Indonesia, Depok

\section{Indonesia}

Correspondence: Fitria Dwi Pratiwi. 16424. Indonesia. E-mail: fitriaadwi@gmail.com 


\section{Abstract}

Introduction. This study examined the theoretical model of peer social support's mediation in the effect that social skills have on the academic self-concept of students with special needs in inclusive primary schools. Students' academic self-concept was measured using the Academic Self-Concept Questionnaire, social skills using the Social Skills Improvement System, and peer social support using the Social Support Questionnaire for Children. Respondents were $292,4^{\text {th }}-6^{\text {th }}$ grade students with special needs in inclusive primary schools in five areas of Jakarta Province.

Method. This study uses quantitative and non-experimental research methods to reveal the relationship among three variables: peer social support, social skills, and academic selfconcept.

Results. The results showed that peer social support mediates social skills' effect on the academic self-concept of students with special needs in inclusive primary schools. These results showed that through peer social support, social skills positively affect the academic selfconcept of students with special needs in inclusive primary schools. However, peer social support is only a partial mediator, meaning that social skills remain strong and significantly and directly affect the academic self-concept of students with special needs in inclusive primary schools.

Discussion and Conclusion. These findings suggest that students' social skills and peer social support should be the primary focus of school personnel for improving the academic selfconcept of students with special needs in inclusive primary schools.

Keywords: academic self-concept, social skills, social support, special needs student, inclusive education. 


\section{Resumen}

Introducción. Este estudio examinó el modelo teórico de la mediación del apoyo social entre pares en el efecto que las habilidades sociales tienen en el autoconcepto académico de los estudiantes con necesidades especiales en escuelas primarias inclusivas. El autoconcepto académico de los estudiantes se midió con el Academic Self-Concept Questionnaire, las habilidades sociales con el Self-Concept Questionnaire y el apoyo social entre pares con el Social Support Questionnaire for Children. Los participantes fueron 292 estudiantes de $4^{\circ}$ a $6^{\circ}$ grado con necesidades especiales en escuelas primarias inclusivas en cinco áreas de la provincia de Yakarta.

Método. Este estudio empleó métodos de investigación cuantitativos y no experimentales para revelar la relación entre tres variables: apoyo social entre pares, habilidades sociales y autoconcepto académico.

Resultados. Los resultados mostraron que el apoyo social entre pares media el efecto de las habilidades sociales en el autoconcepto académico de los estudiantes con necesidades especiales en escuelas primarias inclusivas. Además, se obtuvo que a través del apoyo social entre pares, las habilidades sociales afectaron positivamente el autoconcepto académico de los estudiantes con necesidades especiales en escuelas primarias inclusivas. Sin embargo, el apoyo social entre pares fue solo un mediador parcial, lo que significa que las habilidades sociales siguen siendo fuertes y significativas y afectan directamente el autoconcepto académico de los estudiantes con necesidades especiales en escuelas primarias inclusivas.

Discusión y conclusión. Estos hallazgos sugieren que las habilidades sociales y el apoyo social de los estudiantes deberían ser el enfoque principal del personal escolar para mejorar el autoconcepto académico de los estudiantes con necesidades especiales en las escuelas primarias inclusivas.

Palabras clave: autoconcepto académico, habilidades sociales, apoyo social, estudiantes con necesidades especiales, educación inclusiva. 


\section{Introduction}

Children with special needs differ significantly from typically developing children in some important dimensions of their human functioning. They are constrained in achieving physical, psychological, cognitive, and social goals by speech problems, deafness, blindness, and intellectual disability (Mangunsong, 2014). Of course, there are several types of special needs: physical barriers (physical, hearing, or vision impairment), emotional and behavioral disorders (attention-deficit hyperactivity disorder/ADHD, attention-deficit disorder/ADD, Asperger syndrome, autism, Learning Disabilities/LD), and intellectual disability (slow learner, underachiever, Down syndrome).

Children with special needs require specific educational services based on their learning and developmental barriers. One program provided to children with special needs is inclusive education, in which the educational services environment is the same as for typically developing (TD) students (Hallahan \& Kauffman, 2006). In Indonesia, support in the form of state constitutional commitments for children with special needs is guaranteed in Law No. 19 of 2011 on the Ratification of the Convention on the Rights of Persons with Disabilities.

Inclusive education is expected to eliminate gaps between children with typical development and special needs. In an inclusive classroom, the teacher attempts to eliminate students' differences. Thus, each student's learning needs are fulfilled according to their abilities, and children with special needs can maximize their potential (Marti, 2012). In addition, children with special needs also require different learning patterns, generally based on their level of functional development, such as sensorimotor development, cognitive, language skills, self-skills, social interaction skills, and self-concept.

A supportive environment can be built by not using negative labels for students' personalities and being able to help them grow and develop like TD children. Research suggests that positive social interactions between students with and without disabilities have the potential to contribute to social, emotional, and academic development (Brown, Odom, \& McConnell, 2007; Killen \& Copland, 2011) including social well-being (Prinstein \& Dodge, 2008), and increase self-concept (Pijl \& Frostad, 2010). However, despite the potential for social engagement, research suggests that the frequency of interaction among peers with and 
without disabilities is generally low (Carter, Sisco, Brown, Brickham, \& Al-Khabbaz, 2008; and students with disabilities continue to experience less social acceptance, fewer positive social interactions, and be socially rejected relative to their classmates without disabilities (Sullivan et al., 2015). Hence, the child may feel excluded from surrounding life. Such feelings will certainly not remain separate from a human being's self-concept (Adler, 2010).

Academic self-concept is an assessment of students' ability to do academic tasks at school (Lent, 1997), based on their learning experience and interpretation of the school environment (Guay \& Boivin, 2003). In addition, learning experience is reflected through the students' ability to express their understanding. Academic self-concept can also be interpreted as specific attitudes, feelings, and perceptions of student's intellectual or academic abilities, selfconfidence, and self-feelings in the academic context (Lent \& Bacon, 2011).

Students' academic self-concept can be influenced by peers (Marsh \& Hau, 2003), with negative feedback from them affecting students' views of their abilities. Students might also be excluded from group activities; this, in turn, develops a negative outlook about school. Consequently, a student may be less motivated, less confident, and become detached from class activities. Thus, socially maladjusted children can form negative academic self-concepts that negatively affect their classroom performance. Zeleke's study (2004) indicated that students with LD have significantly lower scores on academic self-concept measures, compared to their normally achieving (NA) peers. Similar to a previous study by Tabassam and Grainger (2002), both LD and LD/ADHD groups reported significantly lower scores on academic self-concept than their NA peers. The difficulty of social adjustment itself is one factor that inhibits social skills in children with special needs, including those with intellectual disabilities (Ardha, 2017), emotional and behavioral disorders (Gresham, Cook, Crews, \& Kern, 2004), learning disabilities, ADHD, and conduct disorder (Gresham, MacMillan, Bocian, Ward, \& Forness, 1998).

Social skills are behaviors that promote positive interaction with others (Lynch and Simpson 2010). Developing social skills is especially important during elementary school when children begin to adapt to the learning environment that allows them to interact more frequently with peers and teachers (Rimm-Kaufman, Curby, Grimm, Brock, \& Nathanson, 2009). 
Social skills are also linked to peer social support of children with special needs. The relationship between social skills and social support can be seen from research results by Nilsen, Roysamb, and Gustavson (2013) who found that children's depression to be due to the low social support they have received and is also connected to their as yet undeveloped social skills. Elliott, Malecki, and Demaray (2001) stated that friends, parents, and teachers are the main sources for school-age children's support. When children enter the school environment, peer support becomes an important main support for fulfilling their social development (Papalia, Sally, \& Ruth, 2009). Peer support can enhance special needs children's social skills, motivate them to learn, increase their confidence, and foster their feelings of acceptance and respect. Thus, peer support can facilitate success in the task of primary school children's social development (Foster, 2011).

Social support is an important determinant of self-concept (Ikiza \& Cakar, 2010), and lack of it can decrease social competence and create loneliness. More specifically, Hadinata's (2009) study on TD students' attitudes and social support toward their special needs peers revealed that non-disabled students tended to exhibit positive attitudes toward affective (feeling) and conative (behavioral) components. In addition, TD students tended to provide selfesteem, and emotional, instrumental, and informational support to students with special needs. Social support's importance is described in Miller's study (in Bond \& Castagnare, 2006), which found that a child with disabilities having a friend or receiving peer support is an effective form of intervention and education that motivates students with disabilities to learn. Social support benefits children with special needs in both social and educational environments.

\section{Hypotheses}

Ha1: Social skills significantly affect special needs students' academic self-concept in inclusive primary schools.

Ha2: Social skills significantly affect peer social support of students with special needs in inclusive primary schools.

Ha3: Peer social support significantly affects the academic self-concept of students with special needs in inclusive primary schools.

Ha4: Peer social support mediates the influence of social skills on the academic selfconcept of students with disabilities in inclusive primary schools. 


\section{Method}

\section{Participants}

Participants in this study were 292 children with special needs. Their disabilities included emotional disturbances, concentration disorders, intellectual disabilities, and physical impairment with mild disability. The research sample was taken using non-probability sampling methods.

Data was collected at 25 inclusive primary schools in five areas in Jakarta (Male=207; Female=85). Schools selected were those that have special needs students, according to the characteristics of participants selected from the official list of Dinas Pendidikan (Disdik) Jakarta. Participants are those who study at grade 3-5 (age around 10 to 15); they were able to read and understand the reading's content. Table 1 presents the descriptions of the respondent's demographic data.

Table 1. Demographic Data of Respondents Selected for This Study

\begin{tabular}{llcc}
\hline Demographic variable & & $\mathbf{N}$ & \% \\
\hline Gender & Male & 207 & $70.9 \%$ \\
& Female & 85 & $29.1 \%$ \\
\hline Age & 10 years old & 106 & $36.3 \%$ \\
& 11 years old & 96 & $32.9 \%$ \\
& 12 years old & 57 & $19.5 \%$ \\
& 13 years old & 19 & $6.5 \%$ \\
& 14 years old & 7 & $2.4 \%$ \\
& 15 years old & 7 & $2.4 \%$ \\
\hline School grade & $3^{\text {rd }}$ grade & 53 & $18.1 \%$ \\
& $4^{\text {th }}$ grade & 87 & $30 \%$ \\
& $5^{\text {th }}$ grade & 101 & $34.5 \%$ \\
& $6^{\text {th }}$ grade & 51 & $17.4 \%$ \\
\hline
\end{tabular}

\section{Instruments}

For collecting this study's data, the researcher used three measuring tools: the Social Support Questionnaire for Children (SSQC), the Social Skills Improvement System (SSIS), and the Academic Self-Concept Questionnaire (ASCQ). 


\section{Social Support Questionnaire for Children (SSQC)}

The SSQC (Harter, 1985) is a measurement tool used to assess the social support of children from parents, siblings, (nonrelative) adults, and peers. From the test results of the measuring instrument in DKI Jakarta area, the reliability coefficient of Cronbach alpha was 0.832. Based on the validity test using the corrected item-total correlation statistical technique, all items tested have also fulfilled the validity value criteria above 0.3. Based on that, the social support measuring instrument can be said to be reliable and valid for measuring social support for students with special needs in inclusive primary schools.

Student ratings of social support are received from their friends and are measured through self-report using the SSQC (Harter, 1985). The SSQC consists of four dimensions: emotional support (5 items), instrumental support (4 items), informational support (3 items), and appraisal support (4 items). Examples of SSQC items are: "My friends cheer me up when I'm sad," "My friends buy me food," and "My friends agreed to my decision."

SSQC has four item responses: not true $=1$, not always true $=2$, true $=3$, and very true $=4$. The "not true" response means that the statement is very unlike their daily behavior, "not always true" indicates that the statement does not always resemble their daily behavior, the "true" response shows that the statement is similar to their daily behavior, and "very true" means very similar to their daily behavior.

\section{Social Skills Improvement System (SSIS)}

This study used the student SSIS form developed by Gresham and Elliott (2008). The SSIS has good psychometric results. From the test results of the measuring instrument, a reliability coefficient of Cronbach alpha was 0.83 . However, based on the validity test using the corrected item-total correlation statistical technique, there is one item with a validity value below 0.3 . When the item is removed, the Cronbach alpha value increases to .85; so the 24 best items were chosen with a validity coefficient ranging from .32-.70.

According to Gresham and Elliott (2008), the seven dimensions of social skills are communication, cooperation, assertiveness, responsibility, empathy, participation, and selfcontrol. The SSIS has been tested for its validity and reliability in participants with special needs such as autism, ADHD, developmental disorder, emotional and intellectual disorders, learning difficulty, and speech or language disorders (Gresham \& Elliott, 2008). Examples of 
SSIS items are: "When asking others for help, I say "please'," "I do what the teacher asks me to do," and "I feel bad (uncomfortable) when others are sad." SSIS items have four responses that are the same as those in the SSQC (see above).

\section{Academic Self-Concept Questionnaire (ASCQ)}

Developed by Liu, Wang, and Parkins (2005), the ASCQ is used to assess children's academic self-concept. From the test results of the measuring instrument, the reliability coefficient of Cronbach alpha was .63. However, based on the validity test using the corrected item-total correlation statistical technique, the four items contained in this study get a validity value below 0.3 . When the four items are removed, the Cronbach alpha value increases to .73 . Kaplan and Saccuzo (2004) stated that the reliability value is considered good if the reliability coefficient of the measuring instrument is above .70 .

The questionnaire consists of nine items based on two dimensions: student's academic confidence and effort. Examples of ASCQ items are: "Most of my classmates are smarter than I am," "I often feel like quitting school," "I often forget what I have learned," and I do a lot of daydreaming in class." Like the SSQC and the SSIS, ASCQ uses the same four responses (as above).

\section{Procedure}

The procedure began with a screening process and it was conducted on all $3-6^{\text {th }}$ grade students to meet sample characteristics. Informed consent was also received from parents, and they were assured that the identities of all the participants would be kept confidential. After selecting students who met the selection criteria, the respondents were divided into several group (session) consists of 4-5 children. They were given verbal instruction by the researcher and were invited to ask about any unclear items in the questionnaire.

While the respondents completed the questionnaire and demographic data, the researcher conducted direct observation to ensure that they were able to answer the questions. The students' answers were validated by re-asking questions from previous answers, to ensure that the given answers reflected the respondents' intent. One group session takes approximately 30-45 minutes. For participation in this research, the respondents received the rewards of test results and stationery. 


\section{Data Analysis}

After obtaining all the data, the researcher performed analysis with linear and multiple regression techniques using the PROCESS mediation model by Hayes (2013). Descriptive statistics and correlation analysis revealed the relationship between variables.

\section{Preliminary Analysis}

Table 2 shows descriptive statistics for all the variables in the study. Of those, mean scores each show a positive correlation within variables. Overall, Pearson correlation between variables shows some significant relationships among peer social support, social skills, and academic self-concept.

Table 2. Correlation Among Academic Self-Concept, Peer Social Support, and Social Skills

\begin{tabular}{|c|c|c|c|c|c|}
\hline & & $\mathbf{M}$ & SD & Social Skills & $\begin{array}{c}\text { Peer Social } \\
\text { Support }\end{array}$ \\
\hline 1 & Peer Social Support & 2.6 & .38 & $.44 * *$ & \\
\hline 2 & Social Skills & 2.77 & .35 & & $.44 * *$ \\
\hline 3 & $\begin{array}{l}\text { Academic } \\
\text { Concept }\end{array}$ & 3.01 & .47 & $.35 * *$ & $.38 * *$ \\
\hline
\end{tabular}

Note:

Correlation is significant at the level of 0.01 (2-tailed)

$* * p<.01$.

$\mathrm{M}=$ Mean $; \mathrm{SD}=$ Standar deviation

\section{Hypothesis Testing}

In testing the research hypothesis, a simple mediation model from micro's PROCESS (Hayes, 2013) is used. Table 3 shows a summary of this hypothesis testing's results.

\section{Results}

\section{Social Skills and Academic Self-Concept (path c)}

The results of separate linear regression analysis found that students' social skills significantly and positively influenced academic self-concept $(F(1,292)=40.5, p=0.00<.05$, $R^{2}=.12$ ). These results indicate that high social skills improve students' positive academic self-concept. The social skills shown at school are assertiveness, participation, cooperation, responsibility, communication, self-control, and empathy, which are positively and significantly related to students' academic self-concept. 


\section{Social Skills and Peer Social Support (path a)}

Regression analyses demonstrated that social skills significantly and positively influenced peer social support $\left(F(1,25)=71.1, p=0.00<.05, R^{2}=.20\right)$. These results indicate that high social skills improved peer social support received by students with special needs. The relationship between social skills and peer social support perceived by students with special needs also shows the highest and most significant correlation value.

\section{Peer Social Support and Academic Self-Concept}

Separate linear regression analysis results show that peer social support significantly and positively influenced academic self-concept $\left(F(1,292)=40.5, p=0.00<.05, R^{2}=.14\right)$, indicating that a high level of peer social support improves students' academic self-concept. Social supports shown at school are emotional, instrumental, informational, and appraisal support, which are positively and significantly related to students' academic self-concept.

\section{Peer Social Support as Mediator between Social Skills and Academic Self-Concept}

Mediation test results showed that some combination effects of two variables significantly affected academic self-concept. From all research models, analysis found that students' social skills and peer social support together significantly influenced academic self-concept $\left(F(2,291)=33.2, \mathrm{p}=0.00<.05, R^{2}=.19\right)$. As Table 3 illustrates, the total effect is significant ( $\mathrm{p}<0.00)$, CI95 $=[0.2152-0.4078]$, with a coefficient value of $\left(\mathrm{a}^{*} \mathrm{~b}=0.3115\right)$. Direct effect in which social skill influenced academic self-concept was also significant $(p<.05)$, CI95 $=$ [0.0961-03034], with a coefficient value of 0.19.

Table 3. Total Effect, Direct Effect, and Indirect Effect on Academic Self-Concept

\begin{tabular}{|c|c|c|c|c|c|c|}
\hline & & Effect & $P$ & SE & LLCI & ULCI \\
\hline 1. & $\begin{array}{l}\text { Total Effect }=\mathrm{c} \\
\text { (social skills) }\end{array}$ & 0.3115 & 0.00 & 0.0489 & 0.2152 & 0.4078 \\
\hline 2. & $\begin{array}{l}\text { Direct Effect }=\mathrm{c}^{\prime} \\
\text { (social skills) }\end{array}$ & 0.1998 & 0.00 & 0.0527 & 0.0961 & 0.3034 \\
\hline 3. & $\begin{array}{l}\text { Indirect Effect }=\mathrm{a}^{*} \mathrm{~b} \\
\text { (peer social support) }\end{array}$ & 0.1117 & 0.00 & 0.327 & 0.0526 & 0.1792 \\
\hline
\end{tabular}


The result of indirect table tested effect using bootstrap with approximation of 10,000 samples showed that indirect effect had significant effect, $b=0.1117, S E=0.327, C 195=$ [0.0526-0.1792].

\section{Discussion and conclusion}

This study's main result indicated a mediation's effect on peer social support, in turn influencing social skills effect on academic self-concept in students with special needs at inclusive primary schools. Based on the analysis test with the Hayes method, peer social support's mediation effect is partial. However, there is a significant relationship between variables in this research model. When social support is used as a variable mediating the relationship of social skills and academic self-concept, the source of social support should come not only from peers; Wahyuni (2017) found that family social support in the form of parental involvement in children's education shows high results. Parental involvement tends to be high because of the low ability of students with special needs. Thus, parents are more likely to pay attention and to support facilities that improve their children's academic ability (McDonnall \& Giesen, 2012).

The significant and positive correlation between social skills and academic selfconcept aligns with Graham's (2002) findings. It shows that cooperation, a social skill, affects students' academic self-concepts. Significant correlations also occur in the relationship between peer social support and students' academic self-concepts. This result aligns with Kaplan et al.'s study (2007), which indicated that when students receive support and appreciation in the classroom, they feel confident of their academic ability. Furthermore, the correlation test conducted in this study confirmed the relationship between social skills and peer social support, indicating a significant, positive relationship between social skills and peer social support. A previous study by Demaray and Malecki (2002) also found that social support has a positive relationship with social skills. In addition, another study conducted by Hay, Payne, and Chadwick (2004) explain that social skills have a connection with peer support.

Academic self-concept analysis in students with special needs at inclusive primary schools shows high results that differ from previous studies by Zeleke (2004) and Tabassam and Grainger (2002). In this study, development of a positive academic self-concept in stu- 
dents with special needs is caused by acquisition of a high value of academic effort dimensions and student academic self-confidence. Results of social skills research on children with special needs at inclusive primary schools are also in the high category. These results contrast with a previous study conducted by Macintosh and Dissanayake (2006) and Frostad and Pijl (2007). In this study, students and participants have begun to develop social skills, for instance, doing activities with friends, greeting others, smiling and laughing, sharing and working together, playing, and learning how to maintain their appearance (Crawford \& Manassis, 2011). Thus, results of peer social support gained by special needs students at inclusive primary schools show high results. A study conducted by Hadinata (2009) on attitudes and social support of regular students to students with special needs revealed that TD students tend to show positive attitudes on affective (feeling) and conative (behavioral) components. In addition, non-disabled students tended to provide emotional, instrumental, informational, and appraisal support to students with special needs.

Overall, this study's results show that social support partially mediates the effect of social skill on academic self-concept. Social skills still significantly affect academic selfconcept of students with special needs. However, presumably, family social support is the broadest received by students with special needs since parents are an important source of support for children (Papalia, Sally, \& Ruth, 2009).

This study's main objective was to examine the theoretical model of mediation's influence on peer social support that influences social skills and, in turn, the academic selfconcept of students with special needs. There are several conclusions based on the analysis. First, social skills have a significant effect on academic self-concept of special needs students at inclusive primary schools. Second, social skills have a significant effect on peer social support of students with special needs at inclusive primary schools. Third, peer social support has a significant effect on the academic self-concept of students with special needs at inclusive primary schools. Fourth, peer social support partially mediates the effect of social skills on academic self-concepts of students with special needs at inclusive primary schools.

\section{Limitation}

First, during the collecting data process, respondent need more assistance in understanding and filling out statements in the questionnaire. The explanations given to students takes a long time so that sometimes other students get distracted and have an effect on filling 
out the questionnaire. So, it must be checked more carefully because sometimes there are items that are skipped or not filled. Second, lack of supporting data available at school, such as intelligence (IQ) results, so that the determination of the types of special needs of students is still largely based on the teacher's knowledge who accompanied students in class everyday.

\section{Recommendation}

In the future research, researcher needs to consider for using collaborators as research assistants. They can help respondents with special needs in filling data so it can minimize inaccuracies in filling out the research questionnaire and avoiding if there are statements that cannot be filled out. Besides that, the need of adequate supporting data that can be confirmed through the teacher or the school. This is important to avoid doubts or mistakes that might occur when researchers conducted research data collection.

\section{References}

Adler, R. (2010). Study of program inferiority and its psychical compensation. New York: Nervous and Mental Disease Publishing.

Ardha, R.Y (2017). Keterampilan Sosial Anak Tunagrahita Ringan di Sekolah Dasar Inklusif. JASSI_anakku, 18 (2), 46-50.

Atmasari. (2009). Studi Deskriptif Mengenai Konsep Diri Akademik dan Perencanaan Karier Pada Remaja Yang Memiliki Orang Tua Sebagai Tenaga Kerja Indonesia. Retrieved from http://alumni.unair.ac.id/kumpulanfile/743829930.abs.pdf

Bond, R., \& Castagnare, E. (2006). Peer support and inclusive education: an underutilized resource. Theory into Practice, 45 (3), 224-229. https://doi.org/10.1207/s15430421tip4503 4

Brown, Odom, S. L., \& McConnell, S. R. (Eds.). (2007). Social competence of young children: Risk, disability, and intervention. Baltimore, MD: Paul H. Brooks.

Carter, E. W., Sisco, L. G., Brown, L., Brickham, D., \& Al-Khabbaz, Z. A. (2008). Peer interactions and academic engagement of youth with developmental disabilities in inclusive middle and high school classrooms. American Journal on Mental Retardation, 113(6), 479-494. http://dx.doi.org/10.1352/2008.113:479-494

Crawford, M., \& Manassis., K. (2011). Anxiety, social skills, friendship quality, and peer victimization: An integrated model. Journal of Anxiety Disorder, 25, 924-931. https://doi.org/10.1016/j.janxdis.2011.05.005

Demaray, M. K., \& Malecki, C. K. (2002). The relationship between perceived social support and maladjustment for student at risk. Psychology in the School, 305-316. https://doi.org/10.1002/pits.10018

Elliott, S. N., Malecki, C. K., \& Demaray, M. K. (2001). New Directions in Social Skills Assessment and Intervention for Elementary and Middle School Students. In:Exceptionality, 9 (1 \& 2), 19-32. https://doi.org/10.1080/09362835.2001.9666989

Frostad, P., \& Pijl, S. J. (2007). Does being friendly help in making friends? The relation between the social position and social skills of pupils with special needs in mainstream education. European Journal of Special Needs Education, 22(1), 15-30. https://doi.org/10.1080/08856250601082224 
Foster, K. (2011). Using a peer buddy system to increase interaction between students with special needs and their peers. Theses and Dissertations: 257. Retrieved from http://rdw.rowan.edu/etd/257

Gresham, Cook, Crews, \& Kern, L. (2004). Social skills training for children and youth with emotional and behavioral disorders: Validity considerations and future directions. Behavioral Disorders, 30(1), 32-46. https://doi.org/10.1177/019874290403000101

Gresham, F., \& Elliott, S. (2008). Social Skills Improvement System-Rating Scales. Minneapolis: MN: Pearson Assessments.

Gresham., MacMillan., Bocian., Ward, S. L., \& Forness, S. R. (1998). Comorbidity of hyperactivity-impulsivity-inattention and conduct problems: Risk factor in social, affective, and academic domains. Journal of Abrnormal Psychology, 26.

Guay, F. M., \& Boivin, M. (2003). Academic self-concept and academic achievement: developmental perspectives on their causal ordering. Journal of Educational Psychology. 95 (1), 126-136. https://doi.org/10.1037/0022-0663.95.1.124

Hadinata, P. (2009). Kontribusi iklim kelas terhadap motivasi belajar siswa. Depok: Universitas Gunadarma.

Hallahan, D. P., \& Kauffman, J. M. (2006). Exceptional children: Introduction to special education. Boston: Allyn \& Bacon.

Harter, S. (1985). The self-perception profile for children: Revision of the perceived competence scale for children. US: University of Denver.

Hay, D. F., Payne, A., \& Chadwick, A. (2004). Peer relations in childhood. Journal of Child Psychology and Psychiatry, 45, 84-108. https://doi.org/10.1046/j.00219630.2003.00308.x

Huitt, W. (2004). Self-concept and self-esteem. Educational Psychology Interactive. Valdosta, GA: Valdosta State University. Retrieved January 2010, from http://www.edpsycinteractive.org/topics/regsys/self.html

Ikiza, \& Cakar, F. (2010). Perceived social support and self-esteem in adolesence. Procedia Social and Behavioral Sciences, 5, 2338-2342. https://doi.org/10.1016/j.sbspro.2010.07.460

Killen, M., \& Copland, R. J. (Eds.). (2011). Social development in childhood and adolescence: A contemporary reader. New York, NY: Wiley.

Lent, \& Bacon. (2011). Academic self-concept and academic achievement of African American students transitioning from urban to rural schools. US: University of Iowa.

Lent, R. W., Brown, S. D., \& Gore, P. A. (1997). Discriminant and predictive validity of academic self-concept, academic self-efficacy, and mathematics-specific selfefficacy. Journal of Counseling Psychology, 44, 307-315. https://doi.org/10.1037/0022-0167.44.3.307

Liu, \& Wang, C. K. (2005). Academic self-concept: A cross-sectional study of grade and gender differences in a Singapore secondary school. Asia Pacific Education Review, 6 (1), 20-27.

Liu, W. C., Wang, C. K., \& Parkins, E. J. (2005). A longitudinal study of students' academic self-concept in a streamed setting: The Singapore context. The British Journal of Educational Psychology. 75 (4), 567-586. https://doi.org/10.1348/000709905X422

Lynch, S. A., \& Simpson, C. G. (2010). Social Skills: Laying the Foundation for Success. Dimensions of Early Childhood, 38(2), 3-12.

Macintosh, K., \& Dissanayake, C. (2006). Social skills and problem behaviours in school aged children with high-functioning autism and Asperger's disorder. Journal of Autism and Developmental Disorders, 36(8), 1065-1076.

Mangunsong, F. (2014). Psikologi pendidikan anak berkebutuhan khusus (Jilid 1). Depok: Lembaga Pengembangan Sarana Pengukuran dan Pendidikan Psikologi UI (LPSP3 UI). 
Marsh, H., \& Hau, K. (2003). Big-Fish-Little-Pond effect on academic selfconcept: A crosscultural (26-country) test of the negative effects of academically selective schools. Journal of American Psychologist, 364-376. https://doi.org/10.1037/0003066X.58.5.364

Marti, A.D. (2012). Pendidikan Inklusif Di Sekolah Dasar Kota Padang. Jurnal Ilmiah Pendidikan Khusus, 1 (3), 1, (http://ejournal.unp.ac.id/index.php/jupekhu).

McDonnall, M. C., \& Giesen, M. J. (2012). The relationship between parental involvement and mathematics achievement for students with visual impairments. Journal of Special Education, 45(4), 204-215. https://doi.org/10.1177/0022466910365169

Nilsen, W. K., Roysamb \& Gustavson, K. (2013). Social skills and depressive symptoms across adolencence: Social support as mediator in girls versus boys. Journal of Adolescence. 36, 11-20. https://doi.org/10.1016/j.adolescence.2012.08.005

Papalia, E. D., Sally W. O., \& Ruth D. F. (2009). Perkembangan manusia. Jakarta: Salemba Humanika.

Pijl, S. J., \& Frostad, P. (2010). Peer acceptance and self-concept of students with disabilities in regular education. European Journal of Special Needs Education, 25(1), 93-105. https://doi.org/10.1080/08856250903450947

Prinstein, M. J., \& Dodge, K. A. (Eds.). (2008). Understanding peer influence in children and adolescents. New York, NY: Guilford Press.

Rimm-Kaufman, Curby, Grimm, K. J., Brock., \& Nathanson, L. (2009). The contribution of children's self-regulation and classroom quality to children's adaptive behaviors in the kindergarten class- room. Developmental Psychology, 45 (4), 958-972. https://doi.org/10.1037/a0015861

Sullivan, T. N., Sutherland, K. S., Lotze, G. M., Helms, S. W., Wright, S. A., \& Ulmer, L. J. (2015). Problem situations experienced by urban middle school students with high incidence disabilities that impact emotional and behavioral adjustment. Joumal of Emotional and Behavioral Disorders, 23(2), 101-114. https://doi.org/10.1177/1063426614528243

Tabassam, W., \& Grainger, J. (2002). Self-concept, attributional style and self-efficacy beliefs of students with learning disabilities. Learning Disability Quarterly, 25, 141-151. https://doi.org/10.2307/1511280

Undang-Undang Nomor 19 Tahun 2011 Tentang Pengesahan Hak- HakPenyandang Disabilitas (Ratification of the Convention on the Rights of Persons with Disabilities.)

Wahyuni, C. (2017). Pengaruh Keterlibatan Orang Tua terhadap Prestasi Akademik siswa, dimediasi oleh Keterampilan Sosial Siswa Berkebutuhan Khusus di Sekolah Dasar Inklusif. Tesis. Depok: Universitas Indonesia.

Zeleke, S. (2004) Self-Concepts of students with learning disabilities and their normal achieving peers: a review. European Journal of Special Needs Education, 19(2), 142-170. https://doi.org/10.1080/08856250410001678469 